Bangladesh J. PI. Breed. Genet, 24(1): 07-14

\title{
IN VITRO REGENERATION OF POTATO (Solanum tuberosum L.)
}

\author{
M. M. H. Molla, K. M. Nasiruddin ${ }^{1}$, M. Al-Amin, M. S. Haque ${ }^{1}$ and D. Khanam \\ Biotechnology Division \\ Bangladesh Agriculture Research Institute \\ Gazipur 1701, Bangladesh
}

\begin{abstract}
The experiment was conducted during the period from January to December, 2008 at the Laboratory of Biotechnology, Bangladesh Agricultural Research Institute, Gazipur, Bangladesh. A two step procedure was followed for direct plant regeneration of potato. Murashige and Skoog (MS) basal medium supplemented with $0.5 \mathrm{mg} \mathrm{l}^{-1} \mathrm{IBA}$ and $30 \mathrm{~g}$ sugar was used for in vitro potato plants development via nodal cuttings. Leaves and internodes of in vitro grown potato variety Asterix was cultured in instant MS basal medium supplemented with $0.01 \mathrm{mg} \mathrm{l}^{-1}$ IAA, $0.20 \mathrm{mg} \mathrm{l}^{-1} \mathrm{GA} 3,44.0 \mathrm{~g} \mathrm{l}^{-1} \mathrm{CaCl}_{2}, 20 \mathrm{~g}$ sucrose. Eight different concentrations of Zeatin riboside (ZR) viz., 0, 0.1, 1.0, 2.0, 3.0, 4.0, $5.0,6.0 \mathrm{mg} \mathrm{l}^{-1}$ along with above supplements (step II) were tested for in vitro direct regeneration of potato. MS medium supplemented with 4-5 $\mathrm{mg} \mathrm{l}^{-1}$ of ZR performed better in respect of shoot induction from internodal explants. All the internodes produced shoots directly from the basal and apex region within 18-21 days and from the leaves within 21-28 days in $2-5 \mathrm{mg} \mathrm{l}^{-1} \mathrm{ZR}$. Maximum 43.20 and 7.25 shoots were recorded from each internode and leaf explant, respectively. In vitro shoots treated with $0.5 \mathrm{mg} \mathrm{l}^{-1}$ of IBA produced roots profusely within 21 days.
\end{abstract}

Key words: Direct regeneration, zeatin riboside (ZR), explant, internode, leaf, IBA, rooting and potato

\section{INTRODUCTION}

Potatoes (Solanum tuberosum L.) are easily regenerated in vitro (Rabbani et al., 2001). Both callus induction and plant regeneration from explants require the appropriate combinations and concentrations of plant growth regulators in the culture media (Ehsanpour and Jones, 2000; Ahan et al., 2001). Presence of cytokinin is necessary for shoot differentiation. Adventitious shoots have been formed by BAP, zeatin or kinetin supplemented media (Mukherjee et al., 1991; Sharma and Rajam, 1995). They stated that morphogenic response also varied with explants and follows a basipetal pattern where the apex region is better responding than the basal region. Shoot regeneration responses also vary with the cultivar but in most cases cytokinin helps to enhance shoot induction (Linden and Riikonen, 2005). Zeatine riboside (ZR) is an important and well known growth regulator for direct shoot induction (Wendt et al., 2001; Yadav and sticklen, 1995). It reduces callus phase and accelerates bud formation (Beaujean et al., 1998 and Rodriguez et al. (2000). All leaf explants treated with zeatin riboside $\left(3 \mathrm{mg} \mathrm{l}^{-1}\right)$ and IAA $\left(1 \mathrm{mg} \mathrm{l}^{-1}\right)$ induced regeneration and produced green $\&$ morphologically normal plants.

\footnotetext{
${ }^{1}$ Department of Biotechnology, Bangladesh Agricultural University, Mymensingh 2202, Bangladesh.
} 
Doo and Boe (2001) reported that MS medium supplemented with $3.5 \mathrm{mg}^{-1}$ IAA and 4 mg $\mathrm{l}^{-1} \mathrm{ZR}$ produced in vitro plantlets from internodal explants. Under Bangladesh condition, very few reports are available regarding the effects of different concentrations of $\mathrm{ZR}$ on in vitro direct regeneration of potato. The present study was, therefore, undertaken to find out an optimum concentration of ZR for direct in vitro regeneration of potato from internode and leaf explants.

\section{MATERIALS AND METHODS}

In vitro ready plantlets of potato $\mathrm{cv}$. Asterix was used as source material. The in vitro plantlets were propagated on MS medium supplemented with $0.5 \mathrm{mg} \mathrm{l}^{-1}$ IBA and $3 \%$ sugars. The cultures were incubated $16 \mathrm{~h}$ ours under light in a room with temperature $21 \pm 1^{\circ} \mathrm{C}$ with $2500-3000$ lux. After 18 - 21 days, in vitro plants were ready for explants collection.

For culturing the explants, $4.4 \mathrm{~g}$ of instant MS basal medium (Duchefa, Netherlands) and $20 \mathrm{~g}$ sucrose (Biobasic, Canada) were used for preparing one liter medium. $\mathrm{GA}_{3}\left(0.20 \mathrm{mg} \mathrm{l}^{-1}\right)$ and IAA $\left(0.01 \mathrm{mg} \mathrm{l}^{-1}\right)$ were used according to Cearley and Bolyard (1997). The $\mathrm{pH}$ was adjusted to 5.8 before autoclaved and $2 \mathrm{~g}$ gelrite (Biobasic, Canada) was added to solidify the medium. Then the medium was autoclaved at 1.06 $\mathrm{kg} / \mathrm{cm}^{2}$ with $121^{\circ} \mathrm{C}$ for 20 minutes. Zeatin riboside in the medium through filter sterilization and mixed in the medium under the laminar air flow hood when the temperature of medium was come down near about $50^{\circ} \mathrm{C}$. Then $20 \mathrm{ml}$ medium was dispensed into each petri dish and covered by upper plate when the medium was cool down and rapped by Para film. Petri dishes were marked as per treatment and kept in $4^{\circ} \mathrm{C}$. Eight different concentrations of ZR viz., 0, 0.1, 1.0, 2.0, 3.0, 4.0, 5.0, $6.0 \mathrm{mg}^{1^{-1}} \mathrm{mg}$ $1^{-1}$ along with $\mathrm{GA}_{3}$ and IAA were tested in this study.

Explants (internode) were collected from in vitro plantlets of 18 - 21 days old. Only the first 5-6 internodes $(0.5-1.0 \mathrm{~cm}$ long $)$ from the top of the plantlet excluding shoot apex was excised. For leaf explants, thick and healthy leaf blades from the upper nodes of the plants excluding tips and basal portions were cut into $5 \times 5 \mathrm{~mm}$ pieces. The leaf explants were placed upside down on the medium. Both the leaf and internode explants, fifteen and five were placed at every Petri dish, respectively in the above mentioned medium. Petri dishes were para filmed and placed at $23 \pm 1^{\circ} \mathrm{C}$ with $16 / 8 \mathrm{hrs}$ light/dark fluorescent light. Shoots regenerated from the $5 \mathrm{mgl}^{-1} \mathrm{ZR}$ treated explants were transferred to half strength MS medium havinh different concentration of IBA $(0.5$, 1.0, 1.5 and $2.0 \mathrm{mgl}^{-1}$ ). Sometimes rooting is prohibited due to the effect of ZR. To reduce the ZR effect, explants were cultured 2 weeks on hormone free MS medium. The cultures were checked daily to note the response and growth of explants. The experiment was designed in CRD with 7 replications. Each petri dish was considered as single replication which contained 15 and 10 internodal and leaf explants, respectively. Stem diameter was measured by a digital slide calipers. Results were analyzed using MSTATC statistical package. Differences among the means were compared by the Duncan's Multiple Range Test at $1 \%$ level of significant. The percentage data were subjected to appropriate transformation like arcsine and squire root system according to Gomez and Gomez (1984). The regenerated rooted plantlets with 4-5 leaves stage were transferred from culture room and kept in room temperature (approx. $30^{\circ} \mathrm{C}$ ) for $4-5$ days. The plantlets were then removed from the culture tubes and all the adhering media were carefully washed out so that, the root damage was the least. Washed plantlets were planted into small plastic pots containing sterile soil, sand and decomposed cow dung at the ratio of 1: $1: 1$. 


\section{RESULTS AND DISCUSSION}

Cent percent explants produced shoot in 2, 3, $4 \& 5 \mathrm{mg} \mathrm{l}^{-1} \mathrm{ZR}$ and 1, 2, 3, 4 \& 5 $\mathrm{mg}^{-1} \mathrm{ZR}$ in internodes and leaf explants, respectively. The lowest were $91.39 \%$ and $96.16 \%$ in $6 \mathrm{mg} \mathrm{l}^{-1} \mathrm{ZR}$ in internode and leaf explant, respectively (Table 1 and 2). This might be due to the detrimental effect of higher dose of ZR. Moreover, MS medium containing $0.1,1 \mathrm{mg} \mathrm{l}^{-1} \mathrm{ZR}$ and without ZR did not produce any shoot in internode explant (Table 1). On the other hand, leaf explant did not produce any shoot in $0.1 \mathrm{mg} \mathrm{l}^{-1}$ ZR and without ZR supplemented MS medium (Table 2). Days required for new shooting both in internode and leaf explants significantly influenced due to the different levels of ZR. The internode and leaf explants treated with $5 \mathrm{mg} \mathrm{l}^{-1} \mathrm{ZR}$ took 14.47 and 18.32 days for new shooting, respectively (Table 1 and 2). The maximum days required for new shooting were 27.16 and 30.14 days at $6 \mathrm{mg} \mathrm{l}^{-1} \mathrm{ZR}$ in both internode and leaf explants, respectively. Days required for new shooting at $3 \mathrm{mg} \mathrm{l}^{-1}$ and $4 \mathrm{mg} \mathrm{l}^{-1} \mathrm{ZR}$ was statistically identical for internode explants but in case of leaf, it was statistically different. The reason for early shooting might be due to optimum concentration of ZR which enhanced shooting. The treatments differed significantly for the number of shoots per explant both internode and leaf explants. The number of shoots per explant increased with the increasing $\mathrm{ZR}$ concentration up to $5 \mathrm{mg} \mathrm{l}^{-1}$ and onward decreased. The maximum number of shoots per explant were 43.20 and 7.25 were recorded in $5.0 \mathrm{mg} \mathrm{l}^{-1}$ ZR from internode and leaf explant, respectively (Figure 1, Plate 1 and 2). Moreover, the leaf explants injured easily during the manipulation while the internode explants were found much more resistant and more amenable to in vitro conditions. The minimum number of shoots per explant were 18.41 and 2.43 counted in $6 \mathrm{mg} \mathrm{l}^{-1} \mathrm{ZR}$ from internode and leaf explants, respectively. The number of shoots per leaf explant were 6.89 and 7.25 recorded in $4 \mathrm{mg} \mathrm{l}^{-1}$ and $5 \mathrm{mg} \mathrm{l}^{-1} \mathrm{ZR}$ concentrations, respectively.

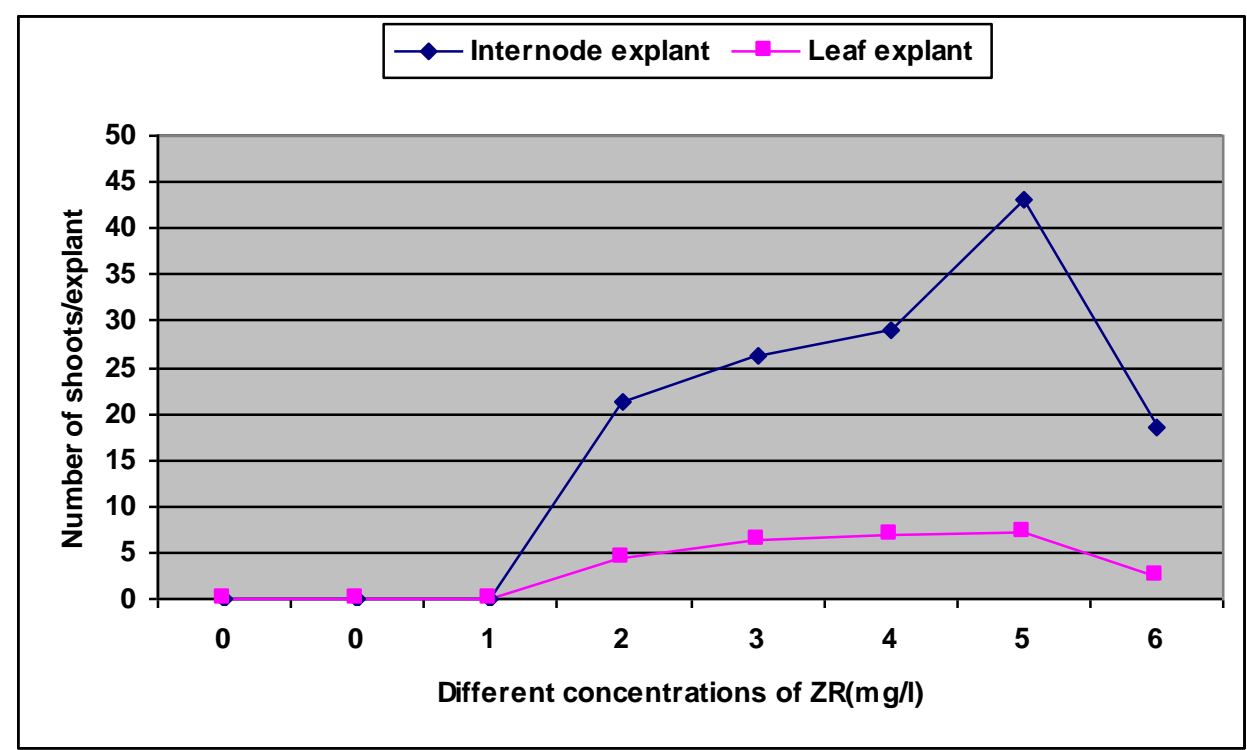

Figure 1. Effects of different concentration of ZR on number of shoots per explant

Significant difference was observed among the treatments for the length of shoot at 28 days. The maximum shoot lengths were 3.20 and $3.43 \mathrm{~cm}$ measured for internode and leaf explants, respectively in $5 \mathrm{mg} \mathrm{l}^{-1} \mathrm{ZR}$ (Table 1 and 2). The minimum length of shoot $(1.56 \mathrm{~cm}$ and $1.68 \mathrm{~cm})$ was recorded in $6 \mathrm{mg} \mathrm{l}^{-1} \mathrm{ZR}$ for internode and leaf explants, 
respectively. Length of shoot for 2, 3, and $4 \mathrm{mg} \mathrm{l}^{-1} \mathrm{ZR}$ for internode and leaf explants were statistically different. The reason for higher shoot length might be due to early shoot initiation. Distinct variation was observed in number of leaves per shoot due to the different levels of ZR concentration both in internode and leaf explants. The result of the study reflected that the longest shoot produced the maximum number of leaves. The maximum number of leaves 3.18 and 3.11 were noted from $5 \mathrm{mg} \mathrm{l}^{-1} \mathrm{ZR}$ treated internode and leaf explants, respectively followed by $2 \mathrm{mg} \mathrm{l}^{-1} \mathrm{ZR}$ (2.73 and 2.68). However, the minimum number of leaves 0.76 and 0.89 was recorded in $6 \mathrm{mg} \mathrm{l}^{-1} \mathrm{ZR}$ treated internode and leaf explants, respectively (Table 1 and 2). There was no statistical difference among the treatments of 2,3 and $4 \mathrm{mg} \mathrm{l}^{-1} \mathrm{ZR}$ for leaves in production internode and leaf explants.

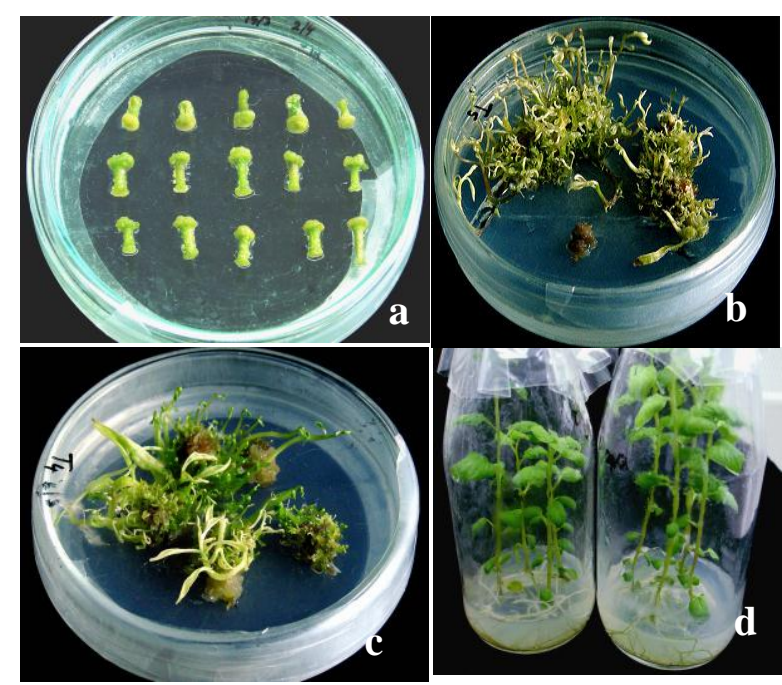

Plate 1. Shoot induction from internode explants of potato cv. Asterix as influenced by $5 \mathrm{mg} \mathrm{l}^{-1} \mathrm{ZR}$ : (a) Internode explants, (b-c) Shoot induction at 21 days and (d) In vitro plant at 28 days.

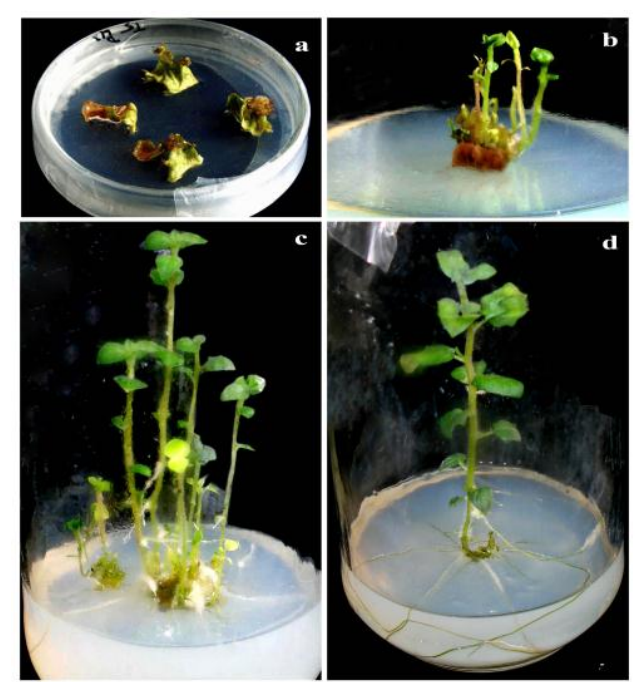

Plate 2. Shoot induction from leaf explants of potato cv. Asterix as influenced by $5 \mathrm{mg} \mathrm{l}^{-1} \mathrm{ZR}$ : (a) Shooting of explants, (b). Shoot induction at 28 days, (c) Shoot induction at 42 days and (d) In vitro plant at 28 days.

Stem diameter significantly influenced due to the different levels of ZR both in internode and leaf explants. The widest shoot diameter $14.12 \mathrm{~mm}$ and $12.39 \mathrm{~mm}$ were recorded from $5 \mathrm{mg} \mathrm{l}^{-1} \mathrm{ZR}$ treated internode and leaf explants, respectively whereas, the lowest $8.14 \mathrm{~mm}$ and $7.31 \mathrm{~mm}$ in $6 \mathrm{mg} \mathrm{l}^{-1} \mathrm{ZR}$ treated internode and leaf explant, respectively (Table 1 and 2). Stem diameter was statistically identical in 4 and $5 \mathrm{mg} \mathrm{l}^{-1}$ ZR treated explants obtained from internode and leaf (Table 1 and 2). Regeneration frequency percentage varied due to different concentration of $\mathrm{ZR}$. The maximum percentage of regeneration frequency (100\%) was recorded in 3, 4 and $5 \mathrm{mg} \mathrm{l}^{-1} \mathrm{ZR}$ for internode and 2, 3, $4 \& \mathrm{mg} \mathrm{l}^{-1}$ for leaf explants. The minimum regeneration frequency percentage was recorded from internode explants in $2 \mathrm{mgl}^{-1} \mathrm{ZR}(31.40 \%)$ whereas, it was lowest of $82.10 \%$ in leaf explants treated with $6 \mathrm{mg} \mathrm{l}^{-1} \mathrm{ZR}$ (Figure 2). Beaujean et al. (1998) stated that it is easier to work with internodal segments which are less sensitive to injuries during different manipulation steps. Moreover older leaves away from the shoot apex are less reactive to the in vitro culture compared to young leaves. 
Table 1. Effect of different concentrations of Zeatin riboside (ZR) on in vitro direct regeneration of potato from internode explants at 28 days

\begin{tabular}{c|c|c|c|c|c}
\hline $\begin{array}{c}\text { ZR } \\
\begin{array}{c}\text { concentrations } \\
\left(\mathrm{mg} \mathrm{l}^{-1}\right)\end{array}\end{array}$ & $\begin{array}{c}\text { Shoot } \\
\text { inducing } \\
\text { explants (\%) }\end{array}$ & $\begin{array}{c}\text { Days } \\
\text { required for shoot } \\
\text { appearance }\end{array}$ & $\begin{array}{c}\text { Length of } \\
\text { shoot } \\
(\mathrm{cm})\end{array}$ & $\begin{array}{c}\text { Number of } \\
\text { Leaves } \\
\text { /shoot }\end{array}$ & $\begin{array}{c}\text { Stem diameter } \\
(\mathrm{mm})\end{array}$ \\
\hline 0.0 & - & - & - & - & - \\
0.1 & - & - & - & - & - \\
1.0 & - & - & - & - & - \\
2.0 & $\begin{array}{c}100.0 \mathrm{a} \\
(86.27)\end{array}$ & $23.13 \mathrm{~b}$ & $2.89 \mathrm{~d}$ & $2.73 \mathrm{~b}$ & $11.17 \mathrm{c}$ \\
3.0 & $\begin{array}{l}100.0 \mathrm{a} \\
(86.27)\end{array}$ & $16.89 \mathrm{c}$ & $2.77 \mathrm{c}$ & $2.51 \mathrm{~b}$ & $12.98 \mathrm{~d}$ \\
4.0 & $\begin{array}{l}100.0 \mathrm{a} \\
(86.27)\end{array}$ & $16.37 \mathrm{c}$ & $2.86 \mathrm{~b}$ & $2.61 \mathrm{~b}$ & $13.42 \mathrm{ab}$ \\
5.0 & $\begin{array}{l}100.0 \mathrm{a} \\
(86.27)\end{array}$ & $14.47 \mathrm{~d}$ & $3.20 \mathrm{a}$ & $3.18 \mathrm{a}$ & $14.12 \mathrm{a}$ \\
6.0 & $\begin{array}{l}91.39 \mathrm{~b} \\
(70.35) \\
\mathrm{CV} \%\end{array}$ & $27.16 \mathrm{a}$ & $1.56 \mathrm{e}$ & $0.76 \mathrm{c}$ & $8.14 \mathrm{~d}$ \\
\hline
\end{tabular}

Means bearing same letters do not differ significantly at $1 \%$ level of probability. Data within parenthesis the arcsin transformed values, $-=$ Absent

Table 2. Effect of different concentrations of Zeatin riboside (ZR) on in vitro direct regeneration of potato from leaf explants

\begin{tabular}{|c|c|c|c|c|c|}
\hline $\begin{array}{c}\text { ZR } \\
\text { concentrations } \\
\left(\mathrm{mg} \mathrm{l}^{-1}\right)\end{array}$ & $\begin{array}{c}\text { Shoot } \\
\text { inducing } \\
\text { explants (\%) }\end{array}$ & $\begin{array}{c}\text { Days } \\
\text { required for } \\
\text { shoot appearance }\end{array}$ & $\begin{array}{l}\text { Length of shoot } \\
(\mathrm{cm})\end{array}$ & $\begin{array}{c}\text { Number of } \\
\text { Leaves } \\
\text { /shoot }\end{array}$ & $\begin{array}{c}\text { Stem } \\
\text { diameter } \\
(\mathrm{mm})\end{array}$ \\
\hline 0.0 & - & - & - & - & - \\
\hline 0.1 & - & - & - & - & - \\
\hline 1.0 & $\begin{array}{l}100.0 \mathrm{a} \\
(86.27)\end{array}$ & - & - & - & - \\
\hline 2.0 & $\begin{array}{l}100.0 \mathrm{a} \\
(86.27)\end{array}$ & $24.89 \mathrm{~b}$ & $2.91 \mathrm{c}$ & $2.68 \mathrm{~b}$ & $10.92 \mathrm{~b}$ \\
\hline 3.0 & $\begin{array}{l}100.0 \mathrm{a} \\
(86.27)\end{array}$ & $23.10 \mathrm{c}$ & $2.83 \mathrm{~b}$ & $2.35 \mathrm{~b}$ & $11.29 \mathrm{~b}$ \\
\hline 4.0 & $\begin{array}{l}100.0 \mathrm{a} \\
(86.27)\end{array}$ & $20.36 \mathrm{~d}$ & $2.90 \mathrm{a}$ & $2.42 \mathrm{~b}$ & $12.12 \mathrm{a}$ \\
\hline 5.0 & $\begin{array}{l}100.0 \mathrm{a} \\
(86.27)\end{array}$ & $18.32 \mathrm{e}$ & $3.43 \mathrm{a}$ & $3.11 \mathrm{a}$ & $12.39 \mathrm{a}$ \\
\hline 6.0 & $\begin{array}{l}96.16 \mathrm{~b} \\
(77.66)\end{array}$ & $30.14 \mathrm{a}$ & $1.68 \mathrm{~d}$ & $0.89 \mathrm{c}$ & $7.31 \mathrm{c}$ \\
\hline CV \% & 3.55 & 8.39 & 11.87 & 8.52 & 9.07 \\
\hline
\end{tabular}

Means bearing same letters do not differ significantly at $1 \%$ level of probability. Data within parentheses the squire root transformed values, - = Absent

On the other hand, ZR reduced the callus phase and accelerated shoot regeneration. These statements are in agreement with the findings of the present study. 


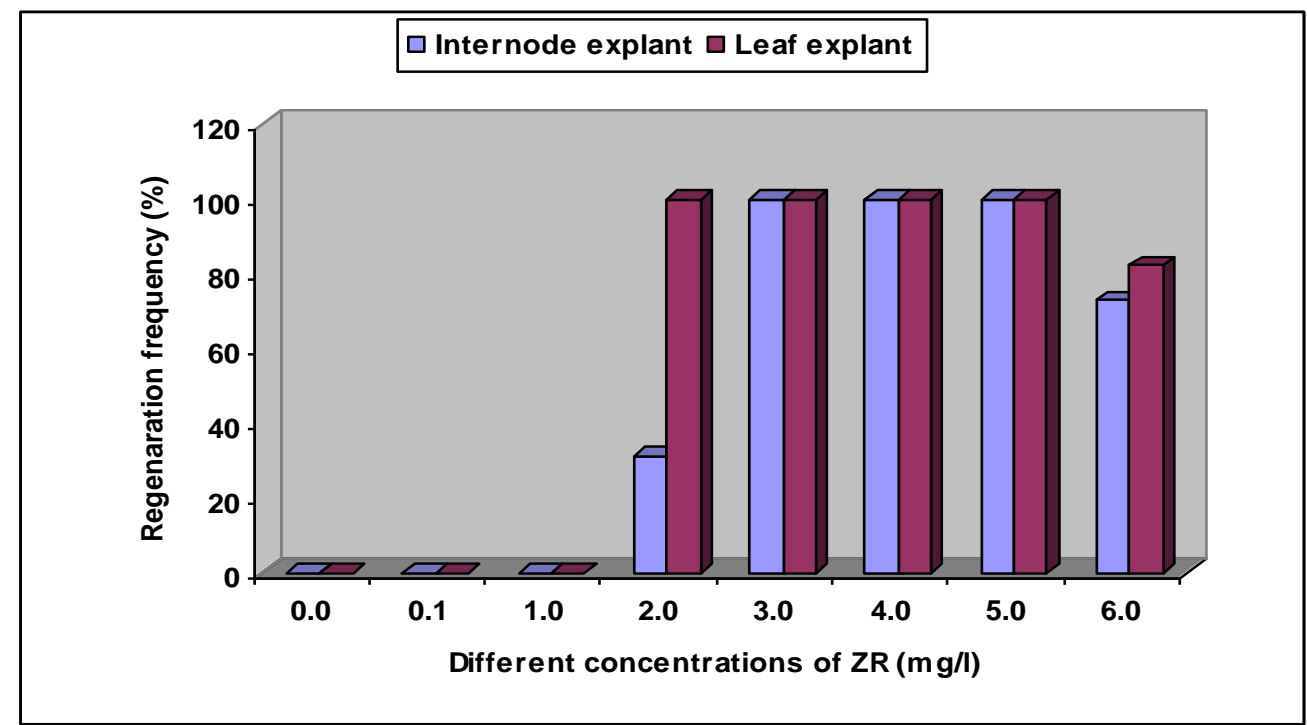

Figure 2. Effect of different concentration of ZR on regeneration frequency

\section{Days to root initiation}

The higher concentration of IBA was statistically superior to the lower concentration regarding the days required for root initiation and ex vitro survival percentage. Cent percentage explants produced roots in medium supplemented with $0.5,1.0,1.5$ and $2.0 \mathrm{mg} \mathrm{l}^{-1}$ IBA within 5-7 days where control treatment needed 9-12 days (Table 3). In vitro treated with $0.5 \mathrm{mgl}^{-1}$ IBA produced healthy and vigorous roots (11.25) having 3.35 secondary roots/root. Other treatments did not produced secondary roots. However, half strength MS medium supplemented with 1.0, 1.5 and $2.0 \mathrm{mg} \mathrm{l}^{-1}$ IBA produced profuse roots resulted into root clump at the basal region of the shoot (Plate 3, Table 3). Moreover, within 12-14 days well developed roots were noted in half strength MS medium supplemented with $0.5 \mathrm{mgl}^{-1}$ IBA (Table 3). Optimum concentration of IBA produced vigorous and healthy feeder roots resulting the secondary roots. Auxin is generally considered necessary for the acquisition of the meristematic competence of the responsive cells. Once this competence has been established, excessive auxin concentration is often found to be inhibitory for further embryonic (Charriere et al., 1999) or adventitious root development (Gurel and Wren, 1995). Cent percent (100\%) survivality was observed in plantlets treated with $0.5 \mathrm{mgl}^{-1} \mathrm{IBA}$ (Table $3)$.

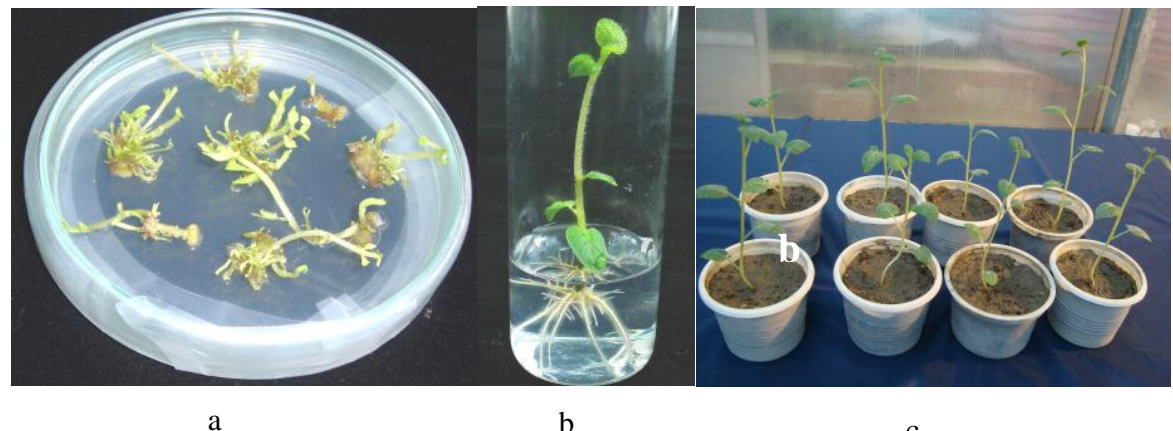

Plate 3. Effect of IBA on rooting of potato cv. Asterix: (a) Shoot induction from internode, (b) Rooted plantlets at 21 days and (c) Ex vitro establishment 
Table 3. Response of IBA on root induction behavior in vitro and ex vitro establishment of plantlet at 28 days

\begin{tabular}{c|c|c|c|c|c|c}
\hline Days to root initiation & $\begin{array}{c}\text { Shoot } \\
\text { inducing root } \\
(\%)\end{array}$ & $\begin{array}{c}\text { Number of } \\
\text { roots } \\
\text { /plant }\end{array}$ & $\begin{array}{c}\text { Number of } \\
\text { secondary } \\
\text { roots/root }\end{array}$ & $\begin{array}{c}\text { Visual } \\
\text { growth of } \\
\text { roots }\end{array}$ & $\begin{array}{c}\text { Days required } \\
\text { for well } \\
\text { developed roots }\end{array}$ & $\begin{array}{c}\text { ex vitro } \\
\text { survival } \\
(\%)\end{array}$ \\
\hline $9-12$ & $100+$ & $3.15 \mathrm{c}$ & 0.0 & + & $18-21$ & $\begin{array}{c}23.40 \mathrm{~d} \\
(27.90)\end{array}$ \\
$7-9$ & $100+$ & $4.25 \mathrm{c}$ & 0.0 & + & $16-18$ & $\begin{array}{c}28.45 \mathrm{~d} \\
(31.10)\end{array}$ \\
$5-6$ & $100+++$ & $11.25 \mathrm{~b}$ & 3.35 & +++ & $12-14$ & $\begin{array}{c}100.00 \mathrm{a} \\
(86.82)\end{array}$ \\
$5-6$ & $100++$ & $18.30 \mathrm{a}$ & 0.0 & + & $14-16$ & $\begin{array}{c}75.39 \mathrm{~b} \\
(58.27)\end{array}$ \\
$5-6$ & $100++$ & $19.35 \mathrm{a}$ & 0.0 & + & $14-16$ & $\begin{array}{c}67.98 \mathrm{bc} \\
(54.79)\end{array}$ \\
$5-6$ & $100++$ & $16.70 \mathrm{a}$ & 0.0 & + & $14-16$ & $\begin{array}{c}59.35 \mathrm{c} \\
(48.75) \\
-\end{array}$ \\
& - & 13.62 & - & - & - & 18.74
\end{tabular}

Means bearing same letters do not differ significantly at $1 \%$ level of probability. Data within parentheses the squire root transformed values. Where,$+=$ Poor,$++=$ Good,$+++=$ Very good, $-=$ Absent .

Based on the above results, it may be concluded that MS medium supplemented with $5 \mathrm{mg} \mathrm{l}^{-1} \mathrm{ZR}$ performed best for in vitro direct regeneration of potato from internodal and leaf explants. Moreover, half strength MS medium supplemented with $0.5 \mathrm{mg} \mathrm{l}^{-1}$ IBA produced well developed roots within 21 days which gave the $100 \%$ survival at ex vitro condition (Plate 3).

\section{Acknowledgement}

The authors are grateful to the HRC-USAID project for financial support to complete the research.

\section{REFERENCES}

Beaujean, A., R. S. Sangwan, A. Lecardonnel and B. S. Sangwan Norreel. 1998. Agrobacterium-mediated transformation of three economically important potato cultivars using sliced internodal explants: an efficient protocol of transformation. J. Expt. Bot. 49: 1589-1595.

Cearley, J. A. and M. G. Bolyard. 1997. Regeneration of Solanum tuberosum cv. Katahdin from leaf explants in vitro. Am. Potato J. 74(2): 125-129.

Charriere, F., B. Sotta, M. Emile and H. Giinther. 1999. Induction of adventitious shoots or somatic embryos of Helianthous annuus: variation of endogenous hormone levels. Plant Physiol Biochem. 17: 751-757.

Doo, P. Y. and A. A. Boe. 2001. Effect of IAA and zeatin riboside on plantlet induction from leaf disks of Solanum tuberosum L. and variation of regenerated plants. Korean Hort. Sci. and Technol. 19(4): 459-464.

Gomez, K. A. and A. A. Gomez. 1984. Statistical Procedures for Agricultural Research ( $2^{\text {nd }}$ Edn.). John Willey and Sons, New York. pp. 207-215.

Gurel, E. and M. J. Wren. 1995. In vitro development from leaf explants of sugar beet (Beta vulgaris L.)- rhizogenesis and the effect of sequential exposure to auxin and cytokinin. Ann. Bot. 75: 31-38.

Linden, L, and A. Riikonen. 2005. Effect of 6-Benzyleaminopurin, thidiazuron and type of explant on in vitro shoot development of Acer platanoides L. Propag. Ornam. Plants. 6: 201-204. 
Mukherjee, S. K., B. Rathnasbapathi and N. Gupta. 1991. Low sugar and osmotic requirements for shoot regeneration from leaf pieces of Solanum melongena L. Plant Cell Tiss. Org., Cult., 25(1): 13-16.

Rabbani, A., B. Askari, N. A. Abbasi, M. Bhatti, A. Quraishi. 2001. Effect of growth regulators on in vitro multiplication of potato. International J. Agric. and Biol., 3(2): 181-182.

Rodriguez, E., C. Trujillo, S. Orduz, S Jaramillo, R. Hoyos and R. Arango. 2000. Standardization of an appropriate culture medium for the regeneration of leaf explants using two Colombian potato varieties (Solanum tuberosum L.). Revista Facul. National de Agron. Msdellin. 53(1): 887-899.

Sharma, P and M. V. Rajam. 1995. Genotype, explant and position effects on organogenesis and somatic embryogenesis in eggplant (Solanum melongena L.). J. Exp. Bot. 46(282): 135-141.

Wendt, S. N., J. A. Peters, A. C. Oliveira, V. L. Bobrowski, F. L. C. Costa, C. S. Madruga and I. L. Vighi. 2001. Plant regeneration and molecular characterization of potato cultivar Macaca, obtained from gamma irradiated explants. J. New Seeds. 3(2): 17-37.

Yadav, N. R. and M. B. Sticklen. 1995. Direct and efficient plant regeneration from leaf explants of Solanum tuberasum L. cv. Bintje. Plant Cell Tissue and Org. Cult. 14: 645-647. 